\title{
Brevundimonas halotolerans sp. nov., Brevundimonas poindexterae sp. nov. and Brevundimonas staleyi sp. nov., prosthecate bacteria from aquatic habitats
}

Correspondence Wolf-Rainer Abraham wab@gbf.de

\author{
Wolf-Rainer Abraham, ${ }^{1}$ Andréia B. Estrela, ${ }^{1}$ Dennis I. Nikitin, ${ }^{2}$ John Smit ${ }^{3}$ \\ and Marc Vancanneyt ${ }^{4}$ \\ ${ }^{1}$ Helmholtz Center for Infection Research, Chemical Microbiology, Inhoffenstrasse 7, 38124 \\ Braunschweig, Germany \\ ${ }^{2}$ Institute of Microbiology, Russian Academy of Sciences, Prospect 60-Letiya Octyabrya 7, korp. 2, \\ Moscow 117811, Russia \\ ${ }^{3}$ University of British Columbia, Dept of Microbiology and Immunology, Vancouver, BC, Canada \\ ${ }^{4}$ BCCM/LMG Bacteria Collection and Laboratory of Microbiology, Ghent University, Ghent, Belgium
}

In a previous study, caulobacteria from a broad range of freshwater, brackish water, marine and soil habitats (Anast \& Smit, 1988; MacRae \& Smit, 1991; Segers et al., 1994) were studied using a polyphasic approach. As a result, the descriptions of the genera Caulobacter and Brevundimonas were emended and a number of Caulobacter species were transferred to the genus Brevundimonas (Abraham et al., 1999). We report here on three novel species within the genus Brevundimonas which emerged from this study.

Strains used in this study were obtained from the American Type Culture Collection (ATCC), the Deutsche Sammlung für Mikroorganismen und Zellkulturen (DSMZ) and the Laboratorium voor Microbiologie, Universiteit Gent,

The GenBank/EMBL/DDBJ accession numbers for the 16S rRNA gene sequences of strains MCS24 ${ }^{\top}, \mathrm{FWC} 40^{\top}, \mathrm{FWC} 3^{\top}, \mathrm{MCS}^{17}, \mathrm{CM} 260$, CM272, CM282 and MCS35 are M83810, AJ227797-AJ227799 and FN397630-FN39763, respectively.

A 16S rRNA gene sequence-based UPGMA tree and details of phospho- and sulfolipids are available as supplementary material with the online version of this paper.
Belgium (LMG), and from one of the authors (J.S.) (CM, FWC and MCS strains) (Table 1). The strains were grown in freshwater Caulobacter medium PYEM $(2 \mathrm{~g}$ peptone, $2 \mathrm{~g}$ yeast extract and $0.5 \mathrm{~g} \mathrm{NH}_{4} \mathrm{Cl}$ per litre $\mathrm{MQ}$ water). After autoclaving and cooling, $5 \mathrm{ml}$ sterile-filtered riboflavin $\left(0.2 \mathrm{mg} \mathrm{ml}^{-1}\right), 2 \mathrm{ml} 50 \%$ glucose (sterile), $1 \mathrm{ml}$ $20 \% \mathrm{MgSO}_{4}$ (sterile) and $1 \mathrm{ml} 10 \% \mathrm{CaCl}_{2}$ (sterile) were added. The strains were grown in 21 flasks at $30{ }^{\circ} \mathrm{C}$ with shaking at 100 r.p.m. and biomass was harvested in the late exponential phase, after $72 \mathrm{~h}$.

For the determination of DNA base compositions, genomic DNA was isolated from $2 \mathrm{ml}$ culture using the DNeasy kit (Qiagen). DNA was digested enzymically and mean G + C contents were determined by HPLC (Tamaoka \& Komagata, 1984). Calculations were carried out according to Mesbah et al. (1989), with non-methylated lambda phage DNA (Sigma) as a standard. For all strains, $\mathrm{G}+\mathrm{C}$ contents between 64.6 and $67.0 \mathrm{~mol} \%$ were found, within the range of those already reported for species of the genus Brevundimonas (Vancanneyt et al., 2005). 
Table 1. Strains used in this study

Accession numbers of sequences determined in this study are in bold.

\begin{tabular}{|c|c|c|}
\hline Strain & Origin & $\begin{array}{l}\text { 16S rRNA gene sequence } \\
\text { accession no. }\end{array}$ \\
\hline \multicolumn{3}{|c|}{$\begin{array}{l}\text { Brevundimonas } \\
\text { halotolerans sp. nov. }\end{array}$} \\
\hline CM260 & J. Poindexter, Woods Hole, MA, USA & FN397630 \\
\hline CM272 & J. Poindexter, Woods Hole, MA, USA & FN397631 \\
\hline CM282 & J. Poindexter, Woods Hole, MA, USA & FN397632 \\
\hline MCS17 & $\begin{array}{l}\text { Brackish water slough adjacent to Arness Park, } \\
\text { Kingston, WA, USA }\end{array}$ & AJ227799 \\
\hline $\operatorname{MCS} 24^{\mathrm{T}}$ & $\begin{array}{l}\text { Brackish water creek flowing into salt water at } \\
\text { Carkeek Park, Seattle, WA, USA }\end{array}$ & M83810 \\
\hline MCS35 & Water of the Baltic Sea north of Rostock, Germany & FN397633 \\
\hline \multicolumn{3}{|c|}{$\begin{array}{l}\text { Brevundimonas poindexterae } \\
\text { sp. nov. }\end{array}$} \\
\hline FWC $40^{\mathrm{T}}$ & $\begin{array}{l}\text { Secondary treatment facility, activated sludge system, } \\
\text { Kelowna, Canada }\end{array}$ & AJ227797 \\
\hline $\begin{array}{l}\text { Brevundimo } \\
{\text { FWC } 43^{\mathrm{T}}}\end{array}$ & $\begin{array}{l}\text { Secondary treatment facility, activated sludge system, } \\
\text { Calgary, Canada }\end{array}$ & AJ227798 \\
\hline
\end{tabular}

The isolates were identified phylogenetically by sequencing of the 16S rRNA genes and by comparison of the sequences with those of type strains. For the PCR, DNA from single colonies was used which had been lysed by exposure to $100 \mu \mathrm{l}$ TE buffer for about $10 \mathrm{~min}$ at $95{ }^{\circ} \mathrm{C}$. Nearly complete 16S rRNA gene sequences were obtained as described previously (Yakimov et al., 2003). The reactions were evaluated on an Applied Biosystems 377 Genetic Analyzer. The program SEQUENCHER version 4.0.5 (Gene Codes Corporation) was used to analyse the sequences. Phylogenetic analysis was made using the CLUSTAL W software (Thompson et al., 1997) for the alignments and the neighbour-joining algorithm and bootstrap percentages based on 1000 replications (Fig. 1) and the UPMGA algorithm with Kimura's two-parameter model was calculated in the software MEGA 3.1. (Kumar et al., 2004) (Supplementary Fig. S1, available in IJSEM Online) using sequences contained in the EMBL database (Kanz et al., 2005). The $16 \mathrm{~S}$ rRNA gene sequences determined have been deposited in the EMBL nucleotide database under the accession numbers listed in Table 1 . The similarity of $16 \mathrm{~S}$ rRNA gene sequences was 97.8, 97.5 and $97.3 \%$ between FWC $40^{\mathrm{T}}$ and Brevundimonas lenta DS- $18^{\mathrm{T}}$, Brevundimonas subvibrioides $\mathrm{CB}^{\mathrm{T}} \mathrm{T}^{\mathrm{T}}$ and Brevundimonas bullata DSM $7126^{\mathrm{T}}$, respectively, and 96.8 and $96.5 \%$ between MCS24 $4^{\mathrm{T}}$ and Brevundimonas variabilis ATCC $15255^{\mathrm{T}}$ and Brevundimonas bacteroides $\mathrm{CB} 7^{\mathrm{T}}$, respectively. The identity between the 16S rRNA gene sequences of FWC43 $3^{\mathrm{T}}$ and $B$. bullata DSM $7126^{\mathrm{T}}$ (Kang et al., 2009) was $98.6 \%$, but the two strains differ sharply in their cell morphology.

For whole-cell fatty acid analysis, cells were saponified $\left[15 \%(\mathrm{w} / \mathrm{v}) \mathrm{NaOH}, 30 \mathrm{~min}, 100{ }^{\circ} \mathrm{C}\right]$, methylated to fatty acid methyl esters (methanolic $\mathrm{HCl}, 10 \mathrm{~min}, 80^{\circ} \mathrm{C}$ ) and extracted (hexane/methyl-tert-butyl ether; $1: 1, \mathrm{v} / \mathrm{v}$ ) as described in detail by Osterhout et al. (1991). Fatty acid methyl esters were analysed on an HP 5890A gas chromatograph. Separation of fatty acid methyl esters was achieved with a fused-silica capillary column $(25 \mathrm{~m}$ by $0.2 \mathrm{~mm}$ ) with cross-linked $5 \%$ phenyl methyl silicone (film thickness $0.33 \mu \mathrm{m}$; HP Ultra 2). The computercontrolled parameters were the same as those described by Osterhout et al. (1991). The instrument was equipped with a flame-ionization detector and an autosampler (HP 7673). The main fatty acids were summed feature 7 (one or more of $\mathrm{C}_{18: 1} \omega 7 c, \mathrm{C}_{18: 1} \omega 9 t$ and $\left.\mathrm{C}_{18: 1} \omega 12 t\right)$ and $\mathrm{C}_{16: 0}$ for all strains; the main hydroxy fatty acid was always $\mathrm{C}_{12: 0} 3$ $\mathrm{OH}$. Strain $\mathrm{FWC} 40^{\mathrm{T}}$ had a rather large amount of 11methyl-12-trans-octadecanoic acid (11-methyl $\mathrm{C}_{18: 1} \omega 5 t$; ECL 18.080) (Abraham et al., 2008), the highest yet reported for a Brevundimonas strain (Table 2).

Polar lipid fatty acid analysis with fast-atom-bombardment mass spectrometry (FAB-MS) was performed in the negative mode on the first of two mass spectrometers of a tandem high-resolution instrument in an $\mathrm{E}_{1} \mathrm{~B}_{1} \mathrm{E}_{2} \mathrm{~B}_{2}$ configuration (JMS-HX/HX110A; JEOL) using the conditions reported by Abraham et al. (1997). In all strains, phosphatidylglycerol, 1,2-di-O-acyl-3-O-[ $\beta$-D-glucopyranosyl- $(1 \longrightarrow 4)-\alpha$-D-glucopyranuronosyl]glycerol, lyso-phosphoglucolipid and 1,2-di-O-acyl-3-O-[6'-(sn-1",2"'-di-Oacyl-glycero- $3^{\prime \prime}$-phosphoryl)- $\alpha$-D-glucopyranosyl]-sn-glycerol were present. Furthermore, sulfoquinovosyl diacylglycerols could be detected in strains CM260, CM272, CM280, MCS17 and MCS24 ${ }^{\mathrm{T}}$ (Supplementary Table S1).

For phenotypic characterization, strains were grown in $20 \mathrm{ml}$ PYEM medium amended with $0,5,10,20,30,40,60$, 80 or $100 \mathrm{~g} \mathrm{NaCl}^{-1}$ at $30{ }^{\circ} \mathrm{C}$. The $\mathrm{OD}_{600}$ of the cell 


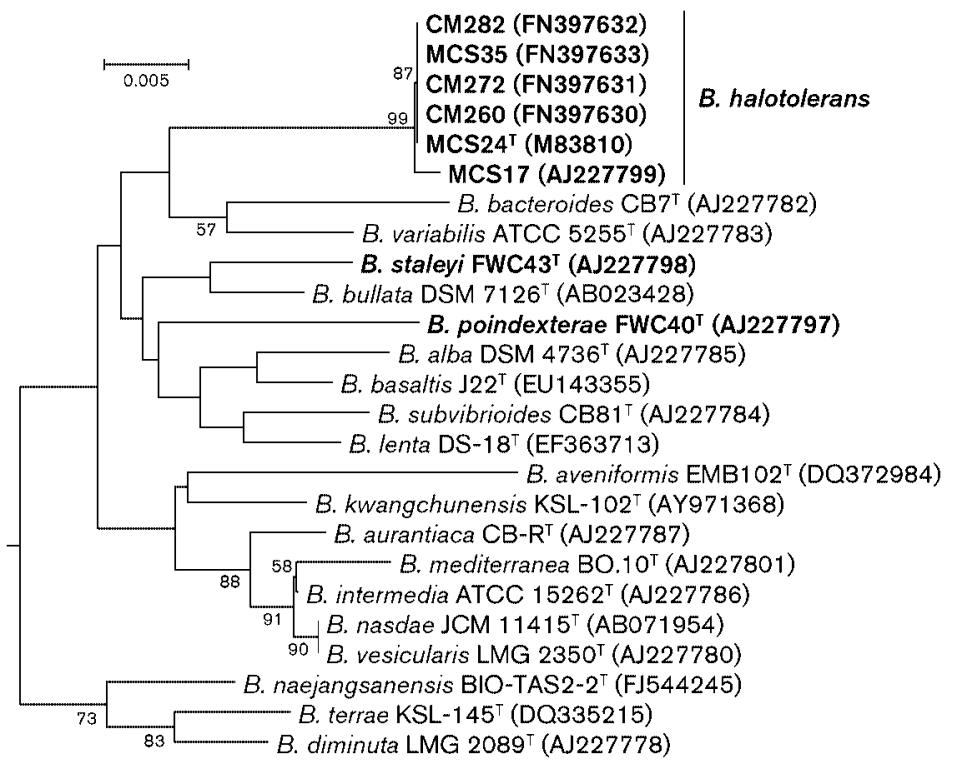

Fig. 1. Unrooted neighbour-joining dendrogram of the phylogenetic relationships between Brevundimonas poindexterae sp. nov. FWC40 ${ }^{\top}$, Brevundimonas staleyi sp. nov. FWC43 ${ }^{\top}$, Brevundimonas halotolerans sp. nov. MCS $24^{\top}$ (and five other strains) and all recognized type strains of the genus Brevundimonas based on a distance-matrix analysis of $16 \mathrm{~S}$ rRNA gene sequences. GenBank accession numbers are given in parentheses. The sequence of Hirschia baltica ATCC $49814^{\top}$ was used as an outgroup (not shown). Bootstrap percentages $>50 \%$ are indicated at tree branching points. Bar, 0.005 substitutions per nucleotide position.

suspension was determined at the beginning of the experiment and after 2 days. The difference between these two measurements was used to determine salt tolerance. All strains could grow with salt concentrations of 5-30 $\mathrm{g} \mathrm{l}^{-1}$ but not with $100 \mathrm{~g} \mathrm{l}^{-1}$. Strain MCS24 ${ }^{\mathrm{T}}$ also showed growth, albeit slow, with salt concentrations up to $80 \mathrm{gl}^{-1}$. Strain FWC40 ${ }^{\mathrm{T}}$ showed reduced growth without $\mathrm{NaCl}$.

Substrate specificity tests were conducted by the use of API Biotype 100 and API 20 NE test strips (bioMérieux) using

Table 2. Fatty acid contents of whole-cell hydrolysates of Brevundimonas strains

Strains: 1, B. alba ATCC $15265^{\mathrm{T}}$; 2, B. aurantiaca ATCC $15266^{\mathrm{T}} ; 3$, B. bacteroides LMG $15096^{\mathrm{T}}$; 4, B. diminuta LMG 2089 ${ }^{\mathrm{T}}$; 5 , B. intermedia ATCC $15262^{\mathrm{T}}$; 6-10, B. halotolerans sp. nov. strains CM260 (6), CM272 (7), CM282 (8), MCS17 (9) and MCS24 ${ }^{\mathrm{T}}$ (10); 11, B. poindexterae sp. nov. FWC40 ${ }^{\mathrm{T}}$; 10, B. staleyi sp. nov. FWC43 ${ }^{\mathrm{T}}$; 13, B. subvibrioides LMG $14903^{\mathrm{T}} ; 14$, B. variabilis ATCC $15255^{\mathrm{T}}$; 15, B. vesicularis $\mathrm{LMG} 2350^{\mathrm{T}}$; 16, B. bullata DSM $7126^{\mathrm{T}}$. Data were obtained in this study. Values are percentages of total fatty acids; only fatty acids accounting for more than $1.0 \%$ (mean amount) are indicated. The following strains contained significant amounts $(>1.0 \%)$ of additional fatty acids: $B$. subvibrioides LMG $14903^{\mathrm{T}}$ also contained $20: 2 \omega 6,9 c(1.6 \%) ; B$. alba also contained $16: 1 \omega 9 c(2.7 \%)$. tr, Trace amount $(<1.0 \%)$; - , not detected; ECL, unknown fatty acid identified by equivalent chain length.

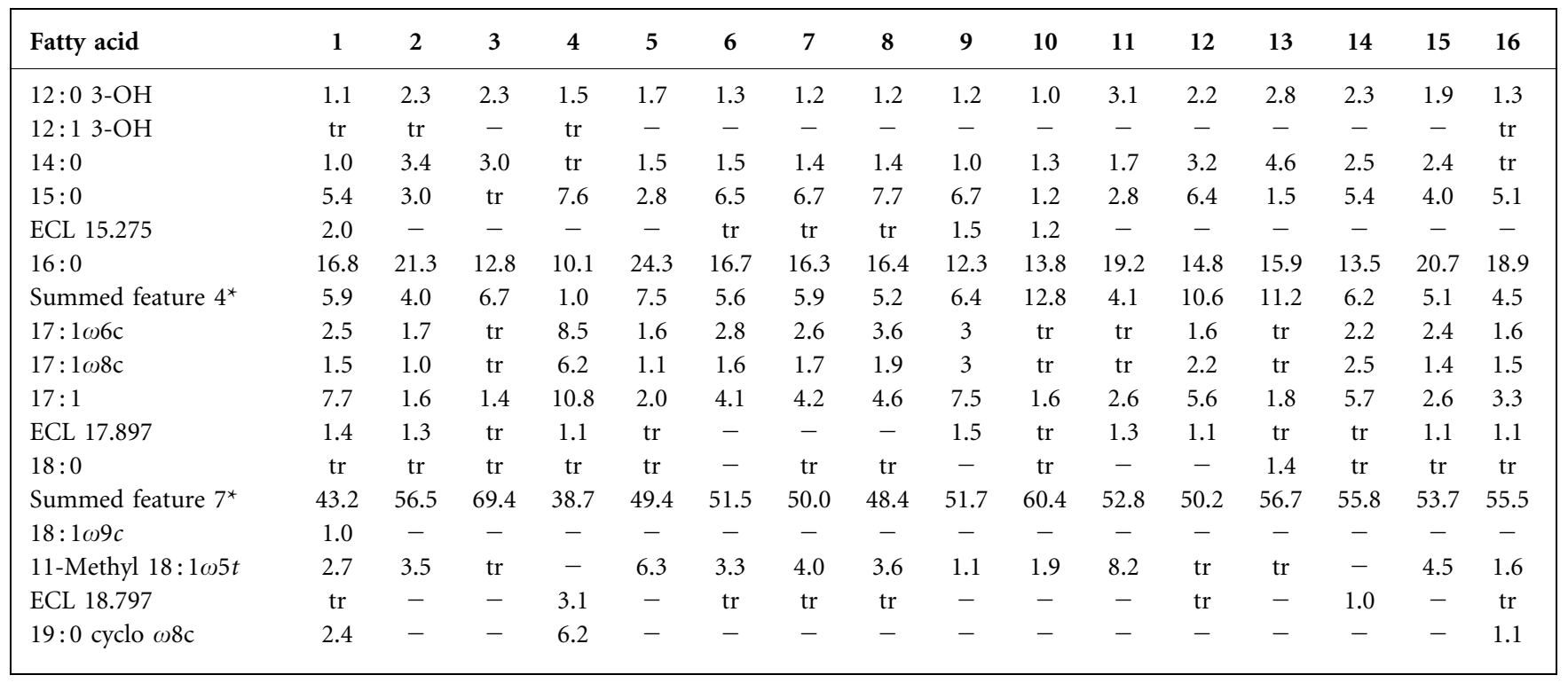

${ }^{*}$ Summed features consist of one or more fatty acids that could not be separated by the Microbial Identification System. Summed feature 4 , one or more of iso-15:0 2-OH, $16: 1 \omega 7 c$ and $16: 1 \omega 7 t$, summed feature 7 , one or more of $18: 1 \omega 7 c, 18: 1 \omega 9 t$ and $18: 1 \omega 12 t$. 
the protocols supplied by the manufacturer. The test strips were incubated at $30{ }^{\circ} \mathrm{C}$ for 14 days and monitored three times a week. A test was considered positive if the interface between sample well and air was visibly turbid due to bacterial growth after incubation for 14 days (Rüger \& Krambeck, 1994). Only strain MCS $24^{\mathrm{T}}$ could reduce nitrate to nitrite. The results for individual strains are given in the species descriptions.

For enzyme activity tests, API ZYM test strips (bioMérieux) were used according to the protocol supplied by the manufacturer. Strains $\mathrm{MCS} 24^{\mathrm{T}}$ and $\mathrm{FWC} 43^{\mathrm{T}}$ showed weak lipase $\left(\mathrm{C}_{14}\right)$ activity, which was absent from $\mathrm{FWC} 40^{\mathrm{T}}$. Leucine arylamidase activity was strong in all strains tested. Cystine arylamidase activity was strong in $\mathrm{MCS}_{2} 4^{\mathrm{T}}$, moderate in $\mathrm{FWC}_{3} 3^{\mathrm{T}}$ but weak in $\mathrm{FWC}^{\mathrm{T}}{ }^{\mathrm{T}}$; acid phosphatase activity was weak in $\mathrm{MCS}_{2} 4^{\mathrm{T}}$ but strong in all other tested strains. The strains also differed in $\alpha$ glucosidase activity, which was strong in $\mathrm{MCS}^{\mathrm{T}} 4^{\mathrm{T}}$ and FWC $43^{\mathrm{T}}$ but absent from FWC40 ${ }^{\mathrm{T}}$. $\beta$-Glucosidase activity was found only in $\mathrm{FWC} 43^{\mathrm{T}}$.
Due to the heterogeneity of the isolates, three different taxa can be discerned and proposals are made of three novel species of Brevundimonas. Discriminating characteristics of the newly proposed species and their nearest neighbours are summarized in Table 3.

\section{Description of Brevundimonas halotolerans sp. nov.}

Brevundimonas halotolerans (ha.lo.to'le.rans. Gr. n. hal, halos salt; L. part. adj. tolerans tolerating; N.L. part. adj. halotolerans salt tolerating).

The description is the same as that given for the genus (Segers et al., 1994; emended by Abraham et al., 1999), with the following additional characteristics. Gram-negative, aerobic, non-spore-forming, prosthecate cells; colonies white coloured, cells bacteroid. $B$. halotolerans has complex substrate requirements and shows optimal growth on peptone-yeast extract medium with $0-40 \mathrm{~g} \mathrm{NaCl}^{-1}$. With $60-80 \mathrm{~g} \mathrm{NaCl} \mathrm{l}^{-1}$, growth is observed, although reduced; no growth is found with $100 \mathrm{~g} \mathrm{NaCl}^{-1}$. Grows optimally

Table 3. Characteristics that are useful in discerning the novel species

Strains: 1, B. poindexterae sp. nov. FWC40 ${ }^{\mathrm{T}} ; 2$, B. staleyi sp. nov. FWC43 ${ }^{\mathrm{T}} ; 3$, B. halotolerans sp. nov. MCS24 $4^{\mathrm{T}} ; 4$, B. terrae KSL-145 ${ }^{\mathrm{T}}($ data from Yoon et al., 2006); 5, B. diminuta LMG 2089 ; 6, B. bullata DSM $7126^{\mathrm{T}}$ (data in columns 5 and 6 from Fritz, 2000); 7, B. variabilis ATCC 15255 ; 8, B. bacteroides $\mathrm{CB}^{\mathrm{T}}$; 9, B. lenta DS- $18^{\mathrm{T}}$ (data in columns 7-9 from Yoon et al., 2007). ++, Strongly positive; +, positive; w, weakly positive; -, negative; ND, no data available.

\begin{tabular}{|c|c|c|c|c|c|c|c|c|c|}
\hline Characteristic & 1 & 2 & 3 & 4 & 5 & 6 & 7 & 8 & 9 \\
\hline \multicolumn{10}{|l|}{ Utilization of: } \\
\hline$\alpha$-D-Glucose & + & + & - & - & - & + & - & - & - \\
\hline D-Galactose & - & - & - & - & - & - & - & $\mathrm{w}$ & - \\
\hline D-Mannose & - & + & - & - & - & - & - & - & - \\
\hline Maltotriose & + & - & - & $\mathrm{ND}$ & - & - & + & - & $\mathrm{ND}$ \\
\hline Maltose & + & - & - & - & - & - & - & - & - \\
\hline Cellobiose & + & + & - & - & - & - & - & - & - \\
\hline Aesculin & + & + & + & - & - & $\mathrm{ND}$ & + & + & + \\
\hline DL-Lactate & - & + & - & - & - & - & + & - & - \\
\hline Succinate & + & + & - & - & - & - & - & - & - \\
\hline Fumarate & + & + & - & ND & - & - & - & + & ND \\
\hline L-Proline & + & + & - & + & ++ & + & - & - & + \\
\hline D-Alanine & - & - & - & ND & + & + & - & - & - \\
\hline L-Alanine & - & $\mathrm{w}$ & - & ND & + & + & - & - & - \\
\hline \multicolumn{10}{|l|}{ Activity of: } \\
\hline Lipase $\left(\mathrm{C}_{14}\right)$ & - & ++ & $\mathrm{W}$ & ND & - & - & $\mathrm{w}$ & - & - \\
\hline Valine arylamidase & + & ++ & ++ & ND & - & ++ & + & + & - \\
\hline Cystine arylamidase & $\mathrm{w}$ & + & ++ & ND & - & - & - & - & - \\
\hline$\alpha$-Chymotrypsin & $\mathrm{W}$ & + & - & $\mathrm{ND}$ & $\mathrm{w}$ & $\mathrm{w}$ & w & $\mathrm{w}$ & - \\
\hline Acid phosphatase & ++ & ++ & $\mathrm{W}$ & ND & ++ & ++ & $\mathrm{w}$ & $\mathrm{w}$ & + \\
\hline Naphthol-AS-BI-phosphohydrolase & ++ & ++ & ++ & ND & ++ & ++ & $\mathrm{w}$ & $\mathrm{w}$ & + \\
\hline$\alpha$-Glucosidase & - & + & ++ & ND & - & $\mathrm{W}$ & - & - & + \\
\hline$\beta$-Glucosidase & - & + & - & ND & - & - & - & - & - \\
\hline Protease & - & + & + & ND & ND & + & ND & ND & + \\
\hline$\beta$-Galactosidase & - & + & - & - & ND & - & $\mathrm{ND}$ & ND & - \\
\hline Reduction of nitrates to nitrites & - & - & + & - & ND & - & ND & ND & - \\
\hline DNA G $+\mathrm{C}$ content $(\mathrm{mol} \%)$ & 67.0 & 66.5 & 64.6 & 61.8 & 67 & 66.7 & ND & 66 & 68.7 \\
\hline
\end{tabular}


at $20-40{ }^{\circ} \mathrm{C}$; slow growth at $10{ }^{\circ} \mathrm{C}$ and no growth at 5 or $50{ }^{\circ} \mathrm{C}$. Nitrate is reduced to nitrite but not to nitrogen. Shows strong activities of alkaline phosphatase, esterase $\left(\mathrm{C}_{4}\right)$, esterase/lipase $\left(\mathrm{C}_{8}\right)$, naphthol-AS-BI-phosphohydrolase, leucine, valine and cystine arylamidases, trypsin, $\alpha$ glucosidase and protease and weak activities of lipase $\left(\mathrm{C}_{14}\right)$ and acid phosphatase. All strains are characterized by two major fatty acids, $\mathrm{C}_{18: 1} \omega 7$ and $\mathrm{C}_{16: 0}$; minor fatty acids are $\mathrm{C}_{15: 0}, \mathrm{C}_{16: 1} \omega 7, \quad$ iso- $\mathrm{C}_{17: 1} \omega 8, \mathrm{C}_{17: 0}$ and 11-methyl $\mathrm{C}_{18: 1} \omega 5 c$. Polar lipids are $\alpha$-D-glucopyranosyl, $\alpha$-D-glucuronopyranosyl, D-glucopyranosyl-( $1 \rightarrow 4)-\alpha$-D-glucopyranuronosyl, sulfoquinovosyl, phosphatidyl and 6phosphatidyl- $\alpha$-D-glucopyranosyl diacylglycerols. The $\mathrm{G}+\mathrm{C}$ content of the type strain is $64.6 \mathrm{~mol} \%$. Known isolates have been obtained from brackish water or seawater.

The type strain, MCS24 $^{\mathrm{T}}$ (=LMG $25346^{\mathrm{T}}=\mathrm{CCUG}$ $\left.58273^{\mathrm{T}}\right)$, was isolated from brackish water of a creek flowing into salt water at Carkeek Park, Seattle, WA, USA. The species is widespread in the marine environment and is known from the Canadian Pacific coast (strains MCS17 and MCS24 $4^{\mathrm{T}}$ ), the North American Atlantic coast (strains CM260, CM272 and CM282), the Tasman Sea near New Zealand (strains CDF5, CDF18 and CDF35) (Fenton, 1994) and the Baltic Sea (strain MCS35). Its ability to grow both in fresh water and in ocean water may be one reason for this wide distribution.

\section{Description of Brevundimonas poindexterae sp. nov.}

Brevundimonas poindexterae (poin.dex'ter.ae. N.L. gen. n. poindexterae of Poindexter, named to honour Jeanne S. Poindexter, who contributed much to our current understanding of the Caulobacterales).

The description is the same as that given for the genus (Segers et al., 1994; emended by Abraham et al., 1999), with the following additional characteristics. Gram-negative, aerobic, non-spore-forming, prosthecate cells; colonies tan coloured, cells bacteroid. No $S$ layer is detected and multiple bands of polysaccharides are observed (Walker et al., 1992). The species can grow on peptone-yeast extract medium without $\mathrm{NaCl}$, but optimal growth occurs with 5 $30 \mathrm{~g} \mathrm{NaCl}^{-1}$. Can not tolerate salt concentrations above $60 \mathrm{~g} \mathrm{NaCl}^{-1}$. Grows optimally at $20-30{ }^{\circ} \mathrm{C}$; slow growth at $40{ }^{\circ} \mathrm{C}$, no growth at 10 or $50{ }^{\circ} \mathrm{C}$. Can use pyruvate, maltotriose, maltose, 1-O-methyl $\alpha$-galactopyranoside, cellobiose, aesculin, xylose, glucose, rhamnose, malate, galacturonate, succinate, fumarate, 3-hydroxybutyrate, asparagine, L-glutamate and L-proline. In contrast, $\beta$ $(+)$-D-fructose, $(+)$-D-galactose, trehalose, $(+)$-D-mannose, $(+)$-L-sorbose, $(+)$-melibiose, sucrose, $(+)$-raffinose, lactose, lactulose, 1-O-methyl $\beta$-galactopyranoside, $(+)$-gentiobiose, 1-O-methyl $\beta$-glucopyranoside, $(-)$-Dribose, $(+)$-L-arabinose, palatinose, $\alpha$-L-fucose, $(+)$-melezitose, (+)-D- and (-)-L-arabitol, xylitol, dulcitol, D- tagatose, glycerol, myo-inositol, D-mannitol, maltitol, (+ )turanose, D-sorbitol, adonitol, D-lyxose, i-erythritol, 1-Omethyl and 3-O-methyl $\alpha$-D-glucopyranoside, saccharate, mucate, (+)-L-, (-)-D- and meso-tartrate, (+)-D-malate, cis- and trans-aconitate, tricarballylate, citrate, Dglucuronate, 2-keto-D-gluconate, $\mathrm{N}$-acetyl-D-glucosamine, D-gluconate, phenylacetate, protocatechuate, 4-hydroxybenzoate, (-)-quinate, gentisate, 3-hydroxybenzoate, benzoate, $m$-coumarate, trigonelline, betaine, putrescine, 4 -aminobutryate, histamine, DL-lactate, glutarate, DL-glycerate, 5-aminovalerate, ethanolamine, tryptamine, itaconate, L-aspartate, L-glutamate, D- and L-alanine, L-serine, malonate, L-tyrosine and 2-ketoglutarate are not used. Enzymic activity of alkaline and acid phosphatases, esterase $\left(\mathrm{C}_{4}\right)$, esterase lipase $\left(\mathrm{C}_{8}\right)$, leucine arylamidase, valine arylamidase, trypsin, naphthol-AS-BI-phosphohydrolase and $\beta$-glucosidase is present. Nitrate is not reduced to nitrite or to nitrogen. Polar lipids are $\alpha$-D-glucopyranosyl, $\alpha$-D-glucuronopyranosyl, $\quad$ D-glucopyranosyl- $(1 \rightarrow 4)-\alpha$-Dglucopyranuronosyl, phosphatidyl and 6-phosphatidyl- $\alpha$ D-glucopyranosyl diacylglycerols. Characterized by two major fatty acids, $\mathrm{C}_{18: 1} \omega 7$ and $\mathrm{C}_{16: 0}$; minor fatty acids are $\mathrm{C}_{15: 0}, \mathrm{C}_{16: 1} \omega 7, \mathrm{C}_{17: 1} \omega 8$ and 11-methyl $\mathrm{C}_{18: 1} \omega 5$. The main hydroxy-fatty acid is $\mathrm{C}_{12: 0} 3-\mathrm{OH}$. The $\mathrm{G}+\mathrm{C}$ content of the type strain is $67.0 \mathrm{~mol} \%$.

The type strain is $\mathrm{FWC} 40^{\mathrm{T}}$ (=LMG $25261^{\mathrm{T}}=$ CCUG $57883^{\mathrm{T}}$ ), isolated from activated sludge from a secondary treatment facility at Kelowna, British Columbia, Canada.

\section{Description of Brevundimonas staleyi sp. nov.}

Brevundimonas staleyi (sta'ley.i. N.L. gen. n. staleyi of Staley, named to honour the American microbiologist James T. Staley for his contribution to the knowledge of the caulobacteria).

The description is the same as that given for the genus (Segers et al., 1994; emended by Abraham et al., 1999), with the following additional characteristics. Gram-negative, aerobic, non-spore-forming, prosthecate cells; colonies bright yellow coloured, cells bacteroid. No $S$ layer is detected and multiple bands of polysaccharides are observed (Walker et al., 1992). Can grow on peptoneyeast extract medium with $0-40 \mathrm{~g} \mathrm{NaCl} \mathrm{l}^{-1}$, with optimal growth at $5-30 \mathrm{~g} \mathrm{NaCl}^{-1}$. Does not tolerate salt concentrations above $60 \mathrm{~g} \mathrm{NaCl}^{-1}$. Grows best at 20 $40{ }^{\circ} \mathrm{C}$; slow growth at $10{ }^{\circ} \mathrm{C}$ and no growth at 5 or $50{ }^{\circ} \mathrm{C}$. D-Glucose, D-mannose, cellobiose, gentiobiose, 1-O-methyl $\beta$-glucopyranoside, aesculin, $\alpha$-L-rhamnose, gentisate, DLlactate, succinate, fumarate, 3-hydroxybutyrate, L-aspartate, L-glutamate, L-proline, $\mathrm{L}$-alanine, malonate and $\mathrm{L}$ tyrosine are used as substrates. $\beta$ - $(+)$-D-Fructose, $(+)$-Dgalactose, (+)-trehalose, (+)-L-sorbose, (+)-melibiose, sucrose, $(+)$-raffinose, maltotriose, maltose, lactose, lactulose, 1-O-methyl $\alpha$ - and $\beta$-galactopyranoside, $(+)$ gentiobiose, $(-)$-D-ribose, $(+)$-L-arabinose, $(+)$-D-xylose, palatinose, $\alpha$-L-fucose, $(+)$-melezitose, $(+)$-D- and $(-)$-L- 
arabitol, xylitol, dulcitol, D-tagatose, glycerol, myo-inositol, D-mannitol, maltitol, (+)-turanose, D-sorbitol, adonitol, D-lyxose, i-erythritol, 1-O-methyl and 3-O-methyl $\alpha$-Dglucopyranoside, saccharate, mucate, $(+)$-L-, $(-)$-D- and meso-tartrate, $(+)$-D- and (-)-L-malate, cis- and transaconitate, tricarballylate, citrate, D-glucuronate, D-galacturonate, 2-keto-D-gluconate, $\mathrm{N}$-acetyl-D-glucosamine, Dgluconate, phenylacetate, protocatechuate, 4-hydroxybenzoate, (-)-quinate, gentisate, 3-hydroxybenzoate, benzoate, $m$-coumarate, trigonelline, betaine, putrescine, 4-aminobutyrate, histamine, glutarate, DL-glycerate, 5aminovalerate, ethanolamine, tryptamine, itaconate, Lglutamate, D-alanine, L-serine, malonate, L-tyrosine and 2-ketoglutarate are not oxidized. Activities of alkaline and acid phosphatases, esterase $\left(\mathrm{C}_{4}\right)$, esterase lipase $\left(\mathrm{C}_{8}\right)$, leucine and valine arylamidases, trypsin, phosphatase, naphthol-AS-BI-phosphohydrolase, $\alpha$-glucosidase, $\beta$-glucosidase, $\beta$-galactosidase and oxidase and weak activities of lipase $\left(\mathrm{C}_{14}\right)$, cystine arylamidase and $\alpha$-chymotrypsin are present. Nitrate is not reduced to nitrite or to nitrogen. Polar lipids are $\alpha$-D-glucopyranosyl, $\alpha$-D-glucuronopyranosyl, D-glucopyranosyl-( $1 \rightarrow 4)$ - $\alpha$-D-glucopyranuronosyl, phosphatidyl and 6-phosphatidyl- $\alpha$-D-glucopyranosyl diacylglycerols. Characterized by two major fatty acids, $\mathrm{C}_{18: 1} \omega 7$ and $\mathrm{C}_{16: 0}$; minor fatty acids are $\mathrm{C}_{15: 0}, \mathrm{C}_{16: 1} \omega 7$, $\mathrm{C}_{17: 1} \omega 8, \mathrm{C}_{14: 0}$ and $\mathrm{C}_{12: 0} 3-\mathrm{OH}$. The $\mathrm{G}+\mathrm{C}$ content of the type strain is $66.5 \mathrm{~mol} \%$; genome size of the type strain is $2.2 \times 10^{9} \mathrm{Da}$. Closely related to $B$. bullata by $16 \mathrm{~S}$ rRNA gene sequence similarity, but clearly distinct by morphology and cell cycle.

The type strain is $\mathrm{FWC}_{3}{ }^{\mathrm{T}}\left(=\mathrm{LMG} 25262^{\mathrm{T}}=\mathrm{CCUG}\right.$ $57884^{\mathrm{T}}$ ), isolated from activated sludge of a secondary treatment facility at Calgary, Alberta, Canada.

\section{Acknowledgements}

We are indebted to Dagmar Wenderoth, Annette Krüger and Peter Wolff for their excellent technical assistance. This work was supported by grants of the German Federal Ministry for Science, Education and Research (projects no. 0319433C and 01 KI 07 96) and the European Union within the T-project 'High Resolution Automated Microbial Identification and Application to Biotechnologically Relevant Ecosystems'.

\section{References}

Abraham, W.-R., Meyer, H., Lindholst, S., Vancanneyt, M. \& Smit, J. (1997). Phospho- and sulfolipids as biomarkers of Caulobacter, Brevundimonas and Hyphomonas. Syst Appl Microbiol 20, 522539.

Abraham, W.-R., Strömpl, C., Meyer, H., Lindholst, S., Moore, E. R. B., Bennasar, A., Christ, R., Vancanneyt, M., Tindall, B. J. \& other authors (1999). Phylogeny and polyphasic taxonomy of Caulobacter species. Proposal of Maricaulis gen. nov. with Maricaulis maris (Poindexter) comb. nov. as the type species, and emended description of the genera Brevundimonas and Caulobacter. Int J Syst Bacteriol 49, 1053-1073.
Abraham, W.-R., Macedo, A. J., Lünsdorf, H., Fischer, R., Pawelczyk, S., Smit, J. \& Vancanneyt, M. (2008). Phylogeny by a polyphasic approach of the order Caulobacterales, proposal of Caulobacter mirabilis sp. nov., Phenylobacterium haematophilum sp. nov. and Phenylobacterium conjunctum sp. nov., and emendation of the genus Phenylobacterium. Int $J$ Syst Evol Microbiol 58, 1939-1949.

Anast, N. \& Smit, J. (1988). Isolation and characterization of marine caulobacters and assessment of their potential for generic experimentation. Appl Environ Microbiol 54, 809-817.

Fenton, C. D. (1994). The isolation and characterization of Caulobacter from Manawatu water systems. $\mathrm{PhD}$ thesis, Massey University, Palmerston North, New Zealand.

Fritz, I. (2000). Das Bakterioplankton im Westlichen Mittelmeer. PhD thesis, Technical University Braunschweig, Braunschweig, Germany (in German). http://www.biblio.tu-bs.de/ediss/data/20000811a/20000811a. html

Kang, S.-J., Choi, N.-S., Choi, J.-H., Lee, J.-S., Yoon, J.-H. \& Song, J.-J. (2009). Brevundimonas naejangsanensis sp. nov., a novel proteolytic bacterium isolated from soil, and reclassification of Mycoplana bullata into the genus Brevundimonas as Brevundimonas bullata comb. nov. Int J Syst Evol Microbiol 59, 3155-3160.

Kanz, C., Aldebert, P., Althorpe, N., Baker, W., Baldwin, A., Bates, K., Browne, P., van den Broek, A., Castro, M. \& other authors (2005). The EMBL nucleotide sequence database. Nucleic Acids Res 33, D29D33.

Kumar, S., Tamura, K. \& Nei, M. (2004). MEGA3: integrated software for molecular evolutionary genetics analysis and sequence alignment. Brief Bioinform 5, 150-163.

MacRae, J. D. \& Smit, J. (1991). Characterization of caulobacters isolated from wastewater treatment systems. Appl Environ Microbiol 57, 751-758.

Mesbah, M., Premachandran, U. \& Whitman, W. B. (1989). Precise measurement of the $\mathrm{G}+\mathrm{C}$ content of deoxyribonucleic acid by highperformance liquid chromatography. Int J Syst Bacteriol 39, 159167.

Osterhout, G. J., Shull, V. H. \& Dick, J. D. (1991). Identification of clinical isolates of Gram-negative nonfermentative bacteria by an automated cellular fatty acid identification system. J Clin Microbiol 29, 1822-1830.

Rüger, H.-J. \& Krambeck, H.-J. (1994). Evaluation of the BIOLOG substrate metabolism system for classification of marine bacteria. Syst Appl Microbiol 17, 281-288.

Segers, P., Vancanneyt, M., Pot, B., Torck, U., Hoste, B., Dewettinck, D., Falsen, E., Kersters, K. \& De Vos, P. (1994). Classification of Pseudomonas diminuta Leifson and Hugh 1954 and Pseudomonas vesicularis Büsing, Döll, and Freytag 1953 in Brevundimonas gen. nov. as Brevundimonas diminuta comb. nov. and Brevundimonas vesicularis comb. nov., respectively. Int J Syst Bacteriol 44, 499-510.

Tamaoka, J. \& Komagata, K. (1984). Determination of DNA base composition by reversed-phase high-performance liquid chromatography. FEMS Microbiol Lett 25, 125-128.

Thompson, J. D., Gibson, T. J., Plewniak, F., Jeanmougin, F. \& Higgins, D. G. (1997). The CLUSTAL_X windows interface: flexible strategies for multiple sequence alignment aided by quality analysis tools. Nucleic Acids Res 25, 4876-4882.

Vancanneyt, M., Segers, P., Abraham, W.-R. \& De Vos, P. (2005). Genus III. Brevundimonas Segers, Vancanneyt, Pot, Torck, Hoste, Dewettinck, Falsen, Kersters and De Vos 1994, 507 ${ }^{\mathrm{VP}}$ emend. Abraham, Strömpl, Meyer, Lindholst, Moore, Christ, Vancanneyt, Tindall, Bennasar, Smit and Tesar 1999, 1070. In Bergey's Manual of Systematic Bacteriology, 2nd edn, vol. 2, part C, pp. 308-315. Edited 
by D. J. Brenner, N. R. Krieg, J. T. Staley \& G. M. Garrity. New York: Springer.

Walker, S. G., Smith, S. S. \& Smit, J. (1992). Isolation and comparison of the paracrystalline surface layer proteins of freshwater caulobacters. J Bacteriol 174, 1783-1792.

Yakimov, M. M., Giuliano, L., Gentile, G., Crisafi, E., Chernikova, T. N., Abraham, W.-R., Lünsdorf, H., Timmis, K. N. \& Golyshin, P. N. (2003).

Oleispira antarctica gen. nov., sp. nov., a novel hydrocarbonoclastic marine bacterium isolated from Antarctic coastal sea water. Int J Syst Evol Microbiol 53, 779-785.

Yoon, J.-H., Kang, S.-J., Lee, J.-S. \& Oh, T.-K. (2006). Brevundimonas terrae sp. nov., isolated from an alkaline soil in Korea. Int J Syst Evol Microbiol 56, 2915-2919.

Yoon, J.-H., Kang, S.-J., Lee, J.-S., Oh, H. W. \& Oh, T.-K. (2007). Brevundimonas lenta sp. nov., isolated from soil. Int $J$ Syst Evol Microbiol 57, 2236-2240. 